\title{
Perception of Corporate Social Responsibility by Consumers of Danmex: Mexico
}

\author{
Fernando Lambarry ${ }^{1}$, Alma Fuentes ${ }^{1}$, Mara Maricela Trujillo ${ }^{1} \&$ Luis Arturo Rivas ${ }^{1}$ \\ ${ }^{1}$ Instituto Politécnico Nacional, Mexico \\ Correspondence: Fernando Lambarry, Instituto Politécnico Nacional, Mexico. E-mail: flambarry@gmail.com
}

Received: October 31, 2014 Accepted: November 11, 2014 Online Published: January 29, 2015

doi:10.5539/jsd.v8n1p174

URL: http://dx.doi.org/10.5539/jsd.v8n1p174

\begin{abstract}
The business sector is at the frontier of a new paradigm that entails assuming social responsibility for its activities from an increasing social pressure to operate sustainably. Despite a growing literature regarding this topic, is barely analyzed how consumers perceive the social responsibility of corporations, which is the purpose of this study in the company Danmex de México. The research method is based on the linear regression and correlational analysis. The results show discretionary and environmental factors with the highest incidence in the perception of the image in the corporate social responsibility at Danmex, followed by ethical and community factors.
\end{abstract}

Keywords: corporate social responsibility, social responsibility models, perception of corporate social responsibility and corporate image

\section{Introduction}

Over time, in addition of generating profitability for its shareholders, companies have also contributed in some way with the societies of which they are part (World Business Council for Sustainable Development, 1998) through a bond of social responsibility traditionally recognized as philanthropy (Correa, Flynn \& Amit, 2004). But the issue has taken a new interest in which organizations are orienting: to assume responsibility for its operation and the impact on society and natural environment (Labandeira et al., 2007) although in Mexico the corporate social responsibility (CSR ) is in an incipient stage of development, the few companies that have socially responsible programs are usually limited to large companies, subsidiaries of multinationals, or to nationals of large size (Saldaña, 2010; Market \& Garcia, 2007) however, the trend in relation to this indicates that an increasing number of companies are starting to adopt this programs (Meyskens \& Paul, 2010).

However, beyond this voluntary commitment and the fulfillment of regulatory and conventional obligations, companies that promote and invest in social responsibility strategies do it more in response to various social, environmental and economic pressures (International Organization for Standardization, 2010; Commission of the European Communities, 2001) than by their own initiative to help achieve a better society and a cleaner environment; the intention that continues to motivating them is to increase profitability (Commission of the European Communities, 2001).

Nevertheless despite the importance of social responsibility and its imminent development in the business world, there are few studies on how consumers perceive social responsibility. This study aims to identify the factors that influence consumer perception in Danmex and potentially in its image. It seeks that the company focus its responsibility strategies in conciliating social development and preserving its captive market or even increasing their participation (Commission of the European Communities, 2001). To do this, the main models are analyzed as well as specific studies on the subject that have been proposed throughout time in specialized literature. The statistical method used is based on the linear regression and correlational analysis (Fernández \& Baptista, 2010).

\section{Contextual Framework: Danmex and Its Responsible Practices}

The multinational company Groupe Danone based in Paris, France, has as main activity the production of dairy foods and beverages, with a presence on five continents and in 121 countries through 40 manufacturing facilities and three business divisions: dairy products, bottled water and medical nutrition (Danone, 2013). It is one of the top ten dairies in the world with annual sales of 25 billion dollars and 101, 881 workers (Economics, 2013). Danmex, Danone Groupe subsidiary in Mexico, concentrates a participation on mexican market of $19.8 \%$ of all 
processed foods, just below those of bakery (Economics, 2013).

The Group has certified in various areas that support the health and safety with which it operates, such as ISO22000: 2005 of the management system of food safety, the ISO14001 of the environmental management system, the Food Safety System Certification 22000 and the AIB 2012 International Standard. Product of this and for the continued donations to the neediest people in Spain (corporate social responsibility program) in 2011 the company received the "Golden Spike" award given by the Spanish federation of food banks. Of their practices in corporate social responsibility stands out their "Respect" program that encourages suppliers to adopt responsible processes. It also has the Sedex nonprofit organization, to enhance responsible and ethical business practices of their supplying chains. The company has received for ten consecutive years the distinction for being a socially responsible company, awarded by the Mexican Center for Philanthropy and has twice received a special recognition for having the best practices in this area, one in 2009 with the social development project "Seed" in the category of involvement with the community and in 2011 with the "Margarita" project to promote a sustainable model of milk production in the category of quality of life. Danmex currently has various programs of corporate social responsibility, addressing the environmental category (program "My first plant" that consists in reforesting $1 \mathrm{~m} 2$ of Mexican forest by each barcode that consumers register on the website of the project) and continuing with the most impact in the category of involvement with the community and philanthropic ( campaign "build your dream" made in advance, in order that in February the product will be consumed, where a percentage of the sale goes to the house of the friendship to help children with cancer).

Moreover, the European company Vigeo, leader in the classification of the performance in Europe, America and Asia, of companies regarding social responsibility in six areas (human rights, environment, human resources, corporate behavior, corporate governance and community involvement) evaluated Danone Spain in 2011, positioning it as a leader in the food industry with a stable overall score of 60 in base 100.

However, in Mexico the issue of corporate social responsibility is incipient and poorly documented. In the case of the company Danmex, there are no formal mechanisms to identify the factors that influence on perception of the consumer and that could possibly influence the image and future purchases of their products. Therefore the identification of these factors is the aim of this study.

\section{Theoretical Framework: Corporate Social Responsibility}

While a growing attitude of greater demand of the society towards the business activity has led to companies to operate according to codes and standards of responsible behavior, simultaneously in the international context, various initiatives related to principles and fundamental rights within work and other social conditions under the concept of socially responsible corporate behavior, have been signed (International Organization for Standardization, 2010, Commission of the European Communities, 2001). Practices, that companies that have implemented, have realized that benefit their reputation, value and image, including reducing the risk of public opposition to their operations (Correa, Flynn \& Amit, 2004).

Nevertheless that this ethical commitment of companies towards society implies them to act responsibly in managing their relationships with all those actors who have a legitimate interest in the business and not just for its shareholders (World Business Council for Sustainable Development, 1998) defining its social and environmental responsibility, from which these parts, with some interest, expect of it (Correa, Flynn \& Amit, 2004).

Therefore, there is a growing scrutiny and demand from customers and users on the actions of companies in the field of social responsibility and sustainability, thus organizations that will incorporate these requirements into their strategies, will have an important competitive advantage over its competitors (Standard Social Accountability International, 2001). However, there are several companies and organizations that do not conduct processes of consultation with its stakeholders and this absence is paradoxical, given the social commitment of their responsibility.

Empirical studies show that consumers not only want good and safe products, but also be assured that they are produced responsibly from the social point of view. Examples include most of the European consumers, that in a considerable number, claim to be willing to pay more for such products, but so far only a minority actually do so (Commission of the European Communities, 2001). It is for this reason that the influence of social responsibility is recognized indirectly in the performance of an organization, among other things, by its ability to attract and retain customers or users (International Organization for Standardization, 2010).

Recently, several researchers have empirically suggested that corporate social responsibility can be a factor that impacts in the perception of consumers about the image of the company, eventually presenting a greater social 
acceptance and an increase in the disposition of customers to buy their products (Romo \& Rodriguez, 2013; Kim et al., 2011; Chaisurivirat, 2009). Nevertheless, it is known that consumer preferences are continuously changing, besides a high degree of ignorance of responsible practices and their meaning (Bigné et al., 2006, 2005; García de Salmon, Herrero \& Rodriguez 2005; Mohr et al., 2001) in contrast to their willingness to pay more for the products of these companies (Bigne \& Currás, 2008; Fernández \& Merino, 2005). But otherwise, can negatively impact the organization if consumers are wary of these initiatives, perceiving them only for profit and socially irresponsible, getting to cause to companies financial problems (Chaisurivirat, 2009; Smith, 2003).

It is for this reason that corporate social responsibility is considered one of the most innovative and least analyzed strategic concepts, making imperative a more comprehensive knowledge of its functioning (Perez \& Rodriguez, 2011) as well as of the structure of its measurement and evaluation. It is fundamental to know and measure customer expectations in this regard, few empirical attempts have begun to do so but with divergent results in terms of its components (Alvarado \& Schlesinger, 2008), for example the scales proposed by Maignan (2001) and García de los Salmones, Herrero \& Rodríguez (2005) both from the four dimensions established by Carroll (1979) and that give a partial support to the same model (Alvarado \& Schlesinger, 2008), but outside of them, no other that incorporates another perspective of analysis.

\subsection{Models on Corporate Social Responsibility}

The company that aspires to be socially responsible should consider some factors when designing its own social responsibility strategy. Regarding this, there are five most cited models in the literature that propose how to measure it: Carroll (1979), the Organization of the United Nations (1999), the Commission of European Nations (2001), the Mexican Center for Philanthropy [Cemefi] (2010) and the standard ISO 26000: 2010 (2010).

For Carroll (1979) the Corporate Social Responsibility is a way of doing business under four aspects: 1. Economic; referred to financial sustainability, 2. Legal; to comply with its constitutional obligations, 3. Ethical; compliance with the expectations of society and their behavior, that is, to go beyond what is legally established in each country in which it operates, 4. Discretionary or philanthropic; Is the responsibility that the company assumed voluntarily with the society, and that with its performance, helps improving it.

For the United Nations in 1999, in the so-called Global Compact, four basic rights are linked to the social responsibility of corporations: human rights, labor, environment and anti-corruption, in ten universal principles derived from three international declarations: the Universal of Human Rights, the one of Principles of the International Labour Organization and the the one of Rio on Environment and Development (United Nations, no year). On human rights, considers two initiatives in relation to its support: respect in its protection and ensure of not acting as complicit in violations of its compliance. On labor matters, there are four fundaments on which companies are encourage to participate: to support freedom of association and the effective recognition of the right to collective bargaining, to promote the elimination of all forms of forced and compulsory labor, the abolition of child labor and the elimination of discrimination in related to employment. On environment matter, about the prevention regarding environmental problems; adoption of initiatives to promote greater environmental responsibility and encourage the development of environmentally sound technologies.

While in the Social Accountability International standard (2001), for the first time the social responsibility requirements for a company are specified. The standard is based, like the Global Compact, in the respect of international principles: The Universal Declaration of Human Rights, the UN Convention on the Rights of the Child, The United Nations Convention on the Elimination of All Forms of Discrimination against Women and the following Conventions and Recommendations of the International Labour Organization (ILO) Conventions 29 and 105 (forced labor and slavery), Convention 87 (freedom of association) Convention 98 (right to collective bargaining), Conventions 100 and 111 (equal pay for male and female workers for work of equal value; discrimination) Convention 135 (on workers' representatives), Convention 138 and Recommendation 146 (minimum age), Convention 155 and Recommendation 164 (health and safety at work), Convention 159 (Vocational rehabilitation and employment of Disabled Persons) Convention 177 (work at home) and Convention 182 (Worst forms of Child Labour).

On the other hand, the Commission of European Nations (2001) in the so-called Green Book, distinguishes, unlike previous proposals, corporate social responsibility under two approaches: an internal approach whose practices affects workers, their health and safety, in addition to investment in human resources and change management, friendly practices relating to the environment and the diligence of the natural resources used in the production process. In the external approach, social responsibility extends to local communities including a wide range of interlocutors: employees, shareholders, business partners, suppliers, consumers, public authorities and NGOs. Promotes, from these two perspectives, seven principles: 1. Ethics: values and business principles. 2. 
Human rights, labor and employment: a. Respect for freedom of association and the effective recognition of the right to collective bargaining; $b$. The elimination of all forms of forced or compulsory labor; $c$. The effective abolition of child labor, and d. Eliminating any discrimination in respect of employment. 3. Corporate Governability, 4. Impacts on the environment, 5. Relations with suppliers, 6. Philanthropy and social investment and 7. Transparency and accountability.

In Mexico, the Mexican Center for Philanthropy (2010) publishes the distinction for companies that behave in a socially responsible way, which shows that the process to achieve it is based on a self-assessment questionnaire, which is reviewed and approved where appropriate by a group of experts (Saldaña, 2010). It dimensions four factors for a company to be socially responsible: 1. Business Ethics, 2. Quality of life (within companies), 3. Bonding and commitment to the community development and 4. Care and preservation of the environment.

Product of this historical sequence and of the growing importance of social responsibility in the business world is that the International Organization for Standardization (2010) with ISO 26000: 2010 standardizes and provides guidance on the principles that underlie a social responsible behavior in organization. Distinguishes seven fundamental subjects, that cover the most likely impacts economic, environmental and social, that organizations should address: 1. Organizational governance, 2. Human Rights, 3. Labor Practices, 4. Environment, 5. Fair operating practices, 6 . Consumer Affairs and 7. Involvement and community development.

In sum, all models vindicate international fundamental rights for a company to be socially responsible. In principle, they are the respect for the human and labor rights, beyond complying with the requirement of law in this matter and an ethical behavior in their actions. Although ISO 26000, strangely voluntary in nature and not for certification, it seems more a utopian response to a demand and a social pressure that still reflects the lack of commitment of the corporate sector on these issues. Nevertheless, as an international standard, in the ISO 26000 is envisaged in three axes: economic, environmental and social, all the responsibilities that should be assumed by the companies through an ethical, transparent and respectful behavior of international standards, to achieve sustainable development (see Appendix A. Table A1).

\section{Research Method}

This is a correlational research and involved a documental review phase of models of social responsibility, those most cited were selected: the Carroll (1979), the Organization of the United Nations (1999), the Commission of European Nations (2001), the Mexican Center for Philanthropy (2010) and the standard ISO 26000: 2010 (2010) and scales proposed by Maignan (2001) y García de los Salmones, Herrero \& Rodríguez (2005). For the Mexican context, ISO 26000 and Cemefi models were selected. The criteria that justified this choice is that one of them is an accepted international standard while the one from Cemefi for being who has distinguished Danmex as a socially responsible company. Thus, the coincident dimensions in the models are the environmental, social and economic, though the latter was excluded coinciding with García de los Salmones, Herrero \& Rodríguez (2005) and increasing the discretionary factor that, jointly with these authors, was proposed by Maignan in its study (2001). Business ethics was also considered for being a present dimension on all models. They were coded as follows: A environment. C linkage to community (social). E ethics. D discretionary (see Appendix A. Table A3).

\subsection{Content Validity}

For this analysis it was only considered the content validity, which was achieved by building the scale based on the dimensions and attributes proposed by previous models, but selecting those that, with specialist support and feedback, will apply to the particular characteristics about consumer perception of products of Danmex in Mexico. This depuration process consisted of applying a survey of 13 indicators and those who were considered, by the experts, with higher frequencies (minimum values of $80 \%$ coincidence) were selected. In this way four items were removed. The environmental dimension was formed by three indicators: education and environmental culture, sustainable use of resources, society. Linkage with the community by three: health, active community involvement, fair marketing practices. Ethics with two: honesty and ethics. Finally, the discretionary dimension with the donation indicator. It should be mentioned that the participation indicator is formed by two sub-indicators C2 and C3 (see appendix). From this model (now called Lafutruri) was performed and applied a pretest to a sample size of 35 , resulting a Cronbach alpha coefficient of 0.907 . It was also calculated the reliability for each of the subscales. For environment was 0.724 , for linkage with the community 0.776 , ethics 0.814 and discretionary lacked of calculation for being one-dimensional. All factors had values above the minimum recommended value of 0.7 (Hair et al., 1998). 


\subsection{Survey and Sample Size}

A semi-structured survey was applied in person to 280 Danmex product consumers in a Monday to Sunday schedule from 11:00 a.m. to 9:00 p.m. in stores, between December 162013 and January 152014 (Appendix A. Table A2).

The sample was aleatory for convenience, resulting in 250 valid, of which 114 were answered by men and 136 by women, with ages older than 26 years, that indicated a frequency of purchase of these products of at least once a week. Three criteria were the basis for the selection of this company: a) is a company distinguished as socially responsible in Mexico by the Mexican Center for Philanthropy for the past 10 years, b) is a leader in the food industry and c) is a transnational company that would imply the use of better practices in social responsibility.

\section{Results and Discussion}

The Cronbach alpha coefficient for the sample of 250, in the reliability analysis was found to be 0.907 in the scale of image perception of corporate social responsibility in its four dimensions. The analysis of the subscales into consideration to the Alpha coefficient of Cronbach, all resulted with values above the minimum recommended of 0.7 , ethics with 0.795 , linkage with the community with 0.869 , environment with 0.844 and remembering that the discretional factor, as unidimensional, lacks of this type of measurement (Figure 1).

Parallel to this process, was evaluated in a general way the image that consumers perceived of the socially responsible company, using two indicators: performance and interest and their respective items (Do you consider that the company Danmex acts in a socially responsible way and Do you think you that the image of the company Danmex acts with the interest of society in mind?) empirical dimension used in the study of Van (2003), in order to analyze linear regression. This subscale showed a coefficient of Cronbach's Alpha of 0.752 and was correlated with the multidimensional scale of four factors, with the intention of determining the relationship between the two, the correlation coefficient was 0.830 with a significance level of 0.01 (quite acceptable). The model is shown in Appendix B. Figure B2.

In this model strong positive and significant correlations at the 0.01 level between dimensions and image perception of corporate social responsibility were evidenced. This indicates that to a higher value of the factors corresponds greater perception of image. Linear regression showed a coefficient R of 0.831 and R2 of 0.690 and coefficients of significant predictors to 0.01 , as follows (equation 1):

\section{Perception image CSR $=0.812+0.169$ ethic +0.155 linkage with community +0.200 environment} +0.225 discretionary ec 1

It is the discretionary factor the one with highest incidence followed by the one of the environment, what consumers perceive as important: donations or social work supporting the disadvantaged in addition to communication campaigns highlighting environmental accomplishments whenever the companies avoid adversely affect the environment in their production processes, which indicates a concern of the organization for the environment.

In general terms the four dimensions of the construct of perception of the image of social responsibility display a relationship of covariance between moderate to strong evidencing that changes in one of them have an impact, moderately or severely, on the other (Hernández, Collado \& Baptista, 2010).

Finally, the dimensions of perception of social responsibility have an effect of $69 \%$ (standardized regression coefficient) in the image perceived by consumers of the company.

Nevertheless an indicator of future purchase intention was included, in which consumers were asked: Is it likely that in the future you purchase a product from Danmex knowing that the company is socially responsible? The result indicates a correlation of 0.641 (good) significant to a level of 0.01 and a coefficient of determination of 0.411. It demonstrates that CSR practices affect but are not strong in purchase intent of consumers (Figure 3).

\section{Conclusions}

One conclusion that can be delineated in this study is that the attributes of the perception of consumers in CSR confirm some of the findings reported in the literature, that is, is in function on the perception that consumers have about the socially responsible practices of the organization (García de los Salmones, Herrero \& Rodríguez, 2005) which result as fundamental the communication activities of the corporation (David, Kline \& Dai, 2005) and, even more in the incipient case of Mexican companies.

A second conclusion that reinforces the above, is that except for the Carroll model (1979) of more than 30 years 
and with its apparent loss of effect, that of the United Nations (1999), the Commission of European Nations (2001), the Mexican Center for Philanthropy (2010) and the standard ISO 26000: 2010 (2010) although coincident in the dimensions, in some way universal, that integrate social responsibility as economic, social and environmental; none of them present indicators to analyze how the consumer perceives, how it creates a corporate image from it and therefore how it affects in a possible behavior of future purchase (Allen \& Schlesinger, 2008).

The perception of corporate social responsibility is considered a multidimensional construct (Mexican Center for Philanthropy, 2010; ISO 26000: 2010; García de los Salmones, Herrero \& Rodríguez, 2005; Commission of European Nations, 2001; Maignan, 2001; United Nations Organization, 1999; Carroll, 1979) although is not questioned in this research in terms of the number of factorial components often divergent on studies (Alvarado \& Schlesinger, 2008), for the case of Danmex the the Lafutruri model was validated and its indicators show an effect of $69 \%$ (standardized regression coefficient) on the consumer perception of the company, reinforcing the results of Bigne \& Currás, (2008), Fernández \& Merino (2005), García de los Salmones, Herrero \& Rodríguez, (2005) y Maignan (2001).

It is the discretionary factor the most incident with a value of 0.255 , followed by the environmental with 0.200 , and indicators such as donations or social work supporting the disadvantaged, communication campaigns highlighting corporate environmental achievements, avoiding that the organization negatively affects the environment in their production processes and concern about it; are ones perceived of greater importance by the consumer in the image of the company.

Regarding purchase intent it is concluded that $41 \%$ of customers that perceive Danmex as a socially responsible company in general, made purchases in the future again, partially confirming the statement by Bigne \& Currás (2008). It is recommended to Danmex a communication strategy about their responsible practices so that their customers have more information and will value Danmex as a committed company to the community and environment. Although equally maintain and increase their social programs and keep their operations and products environmentally friendly.

However, more studies are required to validate the Lafutruri model as the confirmatory factorial identification of the dimensions and attributes of the perception of corporate social responsibility in order to strengthen the construction and development of a measurement scale, for companies formally consider the initiatives and socially responsible activities as an instrument of development that must be implemented not only for reasons of image or for being morally right, but for the positive impact for the community, workers and self-sustainability of the company.

\section{References}

Alvarado, A., \& Schlesinger, W. M. (2008). Dimensionalidad de la responsabilidad social empresarial percibida y sus efectos sobre la imagen y la reputación: una aproximación desde el modelo de Carroll. Estudios Gerenciales, 24(108), 37-59. http://dx.doi.org/10.1016/s0123-5923(08)70043-3

Bigne, E., \& Currás, R. (2008). ¿Influye la imagen de responsabilidad social en la intención de compra? El papel de la identificación del consumidor con la empresa. Universia Business Review, 10-22.

Bigné, E., Chumpitaz, R., Andreu, L., \& Swaen, V. (2005). Percepción de la responsabilidad social corporativa: un análisis cross-cultural. Universia Business Review, 14-27.

Bigné, E., Chumpitaz, R., Andreu, L., \& Swaen, V. (2006). La influencia de la responsabilidad social corporativa en el comportamiento de compra de estudiantes universitarios. Recuperado el 18 de junio de 2013

http://academia.edu/270010/La_Influencia_De_La_Responsabilidad_Social_Corporativa_En_El_Comporta miento_De_Compra_De_Estudiantes_Universitarios

Chaisurivirat, D. (2009). The effect of corporate social responsibility: Exploring the relationship among CSR, attitude toward the brand, purchase intention, and persuasion knowledge. Tesis University of South Florida Scholar Commons. Retrieved from http://scholarcommons.usf.edu/etd/1894

Comisión de las Comunidades Europeas. (2001). Libro verde. Fomentar un marco europeo para la responsabilidad social de las empresas. Recuperado el 23 de enero de 2014 de: http://eur-lex.europa.eu/LexUriServ/LexUriServ.do?uri=COM:2001:0366:FIN:ES:PDF

Correa, M. E., Flynn, S., \& Amit, A. (2004). Responsabilidad social corporativa en América Latina: una visión empresarial. Santiago de Chile: Naciones Unidas. Recuperado el 20 de enero de 2014 de: 
www.eclac.org/publicaciones/xml/4/14904/lc12104.pdf

Danone. (2013). Danone cuida tu salud. Recuperado el 16 de agosto de 2013 de: https://www.danone.com.mx/

David, P., Kline, S., \& Dai, Y. (2005). Corporate Social Responsibility Practices, Corporate Identity, and Purchase Intention: A Dual-Process Model. Journal of Public Relations Research, 17(3), 291-313. http://dx.doi.org/10.1207/s1532754xjprr1703_4

Economía. (2013). Alimentos Procesados. Unidad de inteligencia de negocios. Distrito Federal: ProMéxico.

García de los Salmones, M., Herrero, A., \& Rodríguez, I. (2005). Influence of corporate social responsibility on loyalty and valuation of services. Journal of Business Ethics, 61(4), 369-385. http://dx.doi.org/10.1007/s10551-005-5841-2

Hernández, R., Fernández, C., \& Baptista, M. (2010). Metodología de la investigación. México: Mc Graw-Hill.

ISO 26000:2010. (2010). Guía de responsabilidad social. Suiza: ISO.

Kim, J. W., Kim, E. J., Kim, S. M., \& Hong, H. G. (2011) Effects of fit with CSR activities and consumption value on corporate image and repurchase intention. International Journal of Business Strategy, 11(1), 35-53.

Labandeira, X., León, C. J., \& Vázquez. M. A. (2007). Economía Ambiental. Madrid: Pearson Prentice Hall.

Lámbarry, F., Rivas, L., \& Trujillo, M. (2013) Desarrollo de una escala de medición de la percepción en la calidad del servicio en los sistemas de autobuses de tránsito rápido a partir del Metrobús de la Ciudad de México. Innovar, 23(50). 79-92.

Landero, R., \& González, M. (2009). Estadística con SPSS y metodología de la investigación. México: Trillas.

Maignan, I. (2001). Consumers' perceptions of corporate social responsibilities: A cross-cultural comparison. Journal of Business Ethics, 30(1), 57-72. http://dx.doi.org/10.1023/A:1006433928640

Mercado, P., \& García, P. (2007). La Responsabilidad Social en empresas del Valle de Toluca (México). Un $\begin{array}{llll}\text { estudio exploratorio. } & \text { Estudios }\end{array}$ http://dx.doi.org/10.1016/S0123-5923(07)70005-0

Meyskens, M., \& Paul, K. (2010). The Evolution of Corporate Social Reporting Practices in Mexico. Journal of Business Ethics, 91, 211-227. http://dx.doi.org/10.1007/s10551-010-0615-x

Mohr, L. A., Webb, D. J., \& Harris, K. (2001). Do consumers expect companies to be socially responsible? The impact of corporate social responsibility on buying behavior. Journal of Consumer Affairs, 35(1), 45-72. http://dx.doi.org/10.1111/j.1745-6606.2001.tb00102.x

Pérez, A., \& Rodríguez I. (2011). Estudio de la imagen de responsabilidad social corporativa: formación e integración en el comportamiento del usuario de servicios financieros. Universidad de CantabriaDepartamento de Administración de Empresas. Recuperado el 16 de marzo de 2013 de: www.tdx.cat/handle/10803/36868

Romo, A. M., \& Rodríguez, K. E. (2013). Percepción del consumidor en la actuación de las empresas socialmente responsables. Temas de comunicación, (26), 35-48.

Saldaña, A. J. (2010). Responsabilidad social empresarial: hacia una agenda de investigación en México. Revista y Organizaciones, 12(24), 75-89.

Smith, N. C. (2003). Corporate social responsibility: Whether or how? California Management Review, 45(4), 52-76. http://dx.doi.org/10.2307/41166188

Social Accountability International. (2001). Responsabilidad Social 8000 (SA8000)- New York.

United Nations. (sin año). Los Diez Principios del Pacto Mundial. Recuperado el 18 de febrero de 2014 de: http://www.unglobalcompact.org/Languages/spanish/Los_Diez_Principios.html

World Business Council for Sustainable Development. (1998). Corporate Social Responsibility. Recuperado el 20 de enero de 2014 de: http://www.wbcsd.org/work-program/business-role/previous-work/corporate-social-responsibility.aspx 


\section{Appendix A}

Table A1. Factors of the main models of corporate social responsibility

\begin{tabular}{|c|c|c|}
\hline Model & Year & Factors \\
\hline Carroll & 1979 & Economic, Legal, Ethical; Discretionary or philanthropic \\
\hline United Nations Global Compact & 1999 & Fundamental rights: human rights, labor, environment and anti-corruption. \\
\hline $\begin{array}{l}\text { Social Accountability International } \\
\text { standard }\end{array}$ & 2001 & Rights: humans, of the Child, of Discrimination against Women and Labour. \\
\hline $\begin{array}{l}\text { Commission of European Nations } \\
\text { (Green Book) }\end{array}$ & 2001 & $\begin{array}{l}\text { 1. Ethics: values and business principles. 2. Human rights, labor and employment: } 3 \text {. } \\
\text { Corporate Governability, } 4 \text {. Impacts on the environment, 5. Relations with suppliers, } 6 \text {. } \\
\text { Philanthropy and social investment and } 7 \text {. Transparency and accountability. }\end{array}$ \\
\hline Mexican Center for Philanthropy & 2010 & $\begin{array}{l}\text { 1. Business Ethics, 2. Quality of life (within companies), 3. Bonding and commitment to } \\
\text { the community development and } 4 \text {. Care and preservation of the environment. }\end{array}$ \\
\hline $\begin{array}{l}\text { Organization for Standardization } \\
\text { with ISO 26000: } 2010\end{array}$ & 2010 & $\begin{array}{l}\text { 1. Organizational governance, 2. Human Rights, 3. Labor Practices, 4. Environment, } 5 . \\
\text { Fair operating practices, 6. Consumer Affairs and } 7 \text {. Involvement and community } \\
\text { development. }\end{array}$ \\
\hline
\end{tabular}

Table A2. Listing of sample information

\begin{tabular}{ll}
\hline Universe & Danmex consumers: 1000. \\
\hline Country / City & México/Ciudad de México. \\
Sample Size & 250 \\
Sampling Error & $5.3 \%$ \\
Confidence level interval & $95 \% . \mathrm{z}=1.96 ; \mathrm{p}=\mathrm{q}=0.5$ \\
Data Collection & Semistructured questionnaire. \\
Date of application & December 16,2013 to January 15,2014 \\
\hline
\end{tabular}


Table A3. Operational of the Lafutruri model (2014)

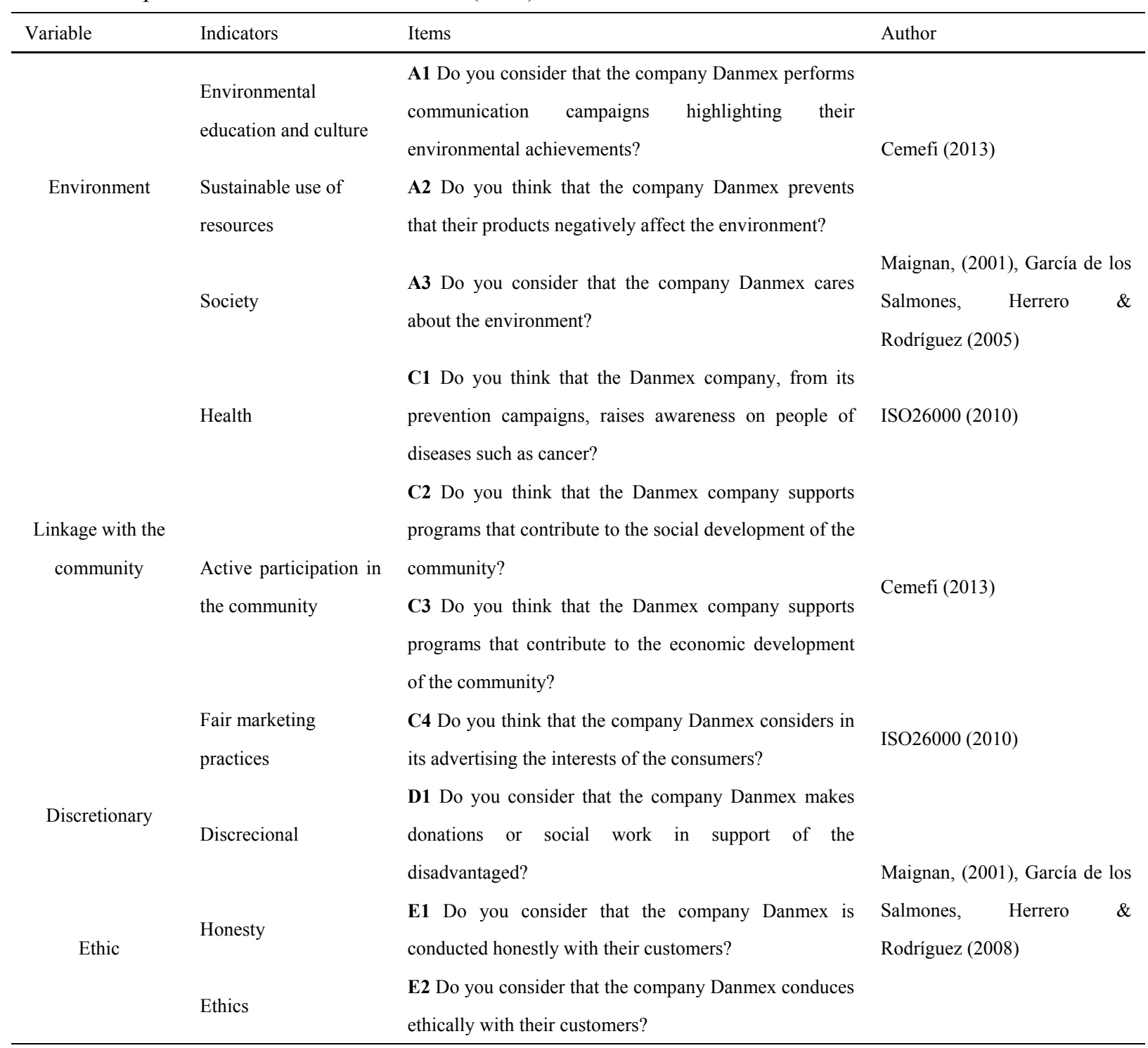




\section{Appendix B}

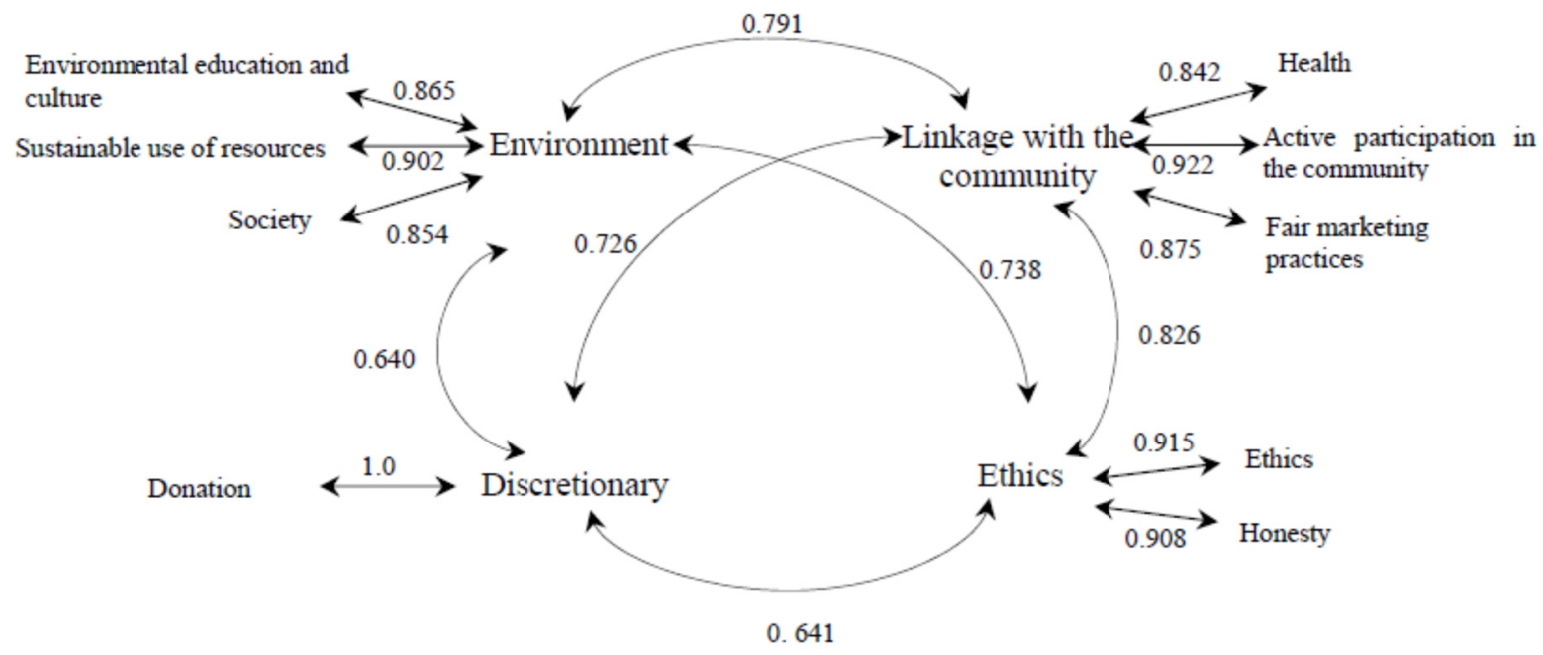

Figure B1. Correlational analysis

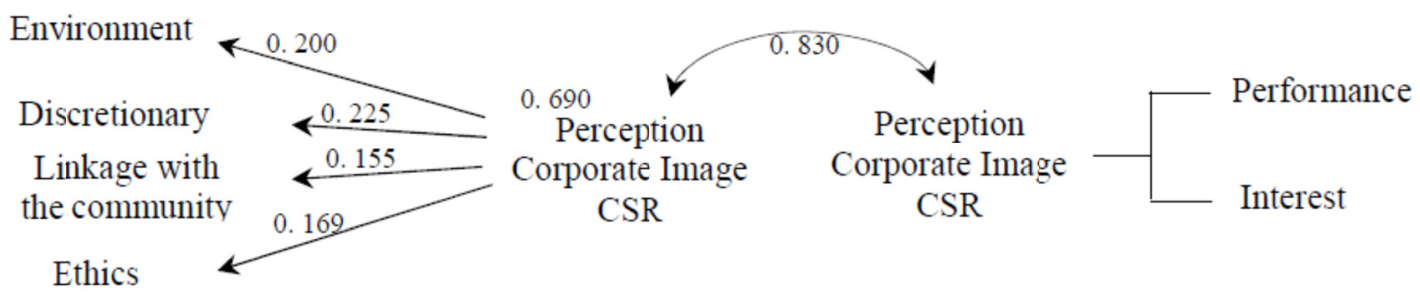

Figure B2. Model of image perception of corporate social responsibility

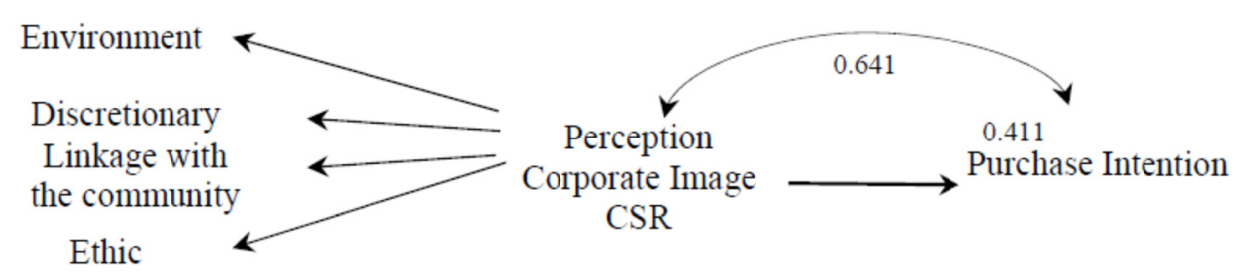

Figure B3. Perception of corporate image CSR and purchase intention

\section{Copyrights}

Copyright for this article is retained by the author(s), with first publication rights granted to the journal.

This is an open-access article distributed under the terms and conditions of the Creative Commons Attribution license (http://creativecommons.org/licenses/by/3.0/). 